\title{
Chemical suppression of fighting in the Siamese fighting fish
}

DONALD H. THOR ${ }^{1}$, MICHAEL H. WEISMAN, STEVEN C. BOSHKA WESTERN MICHIGAN UNIVERSITY

Siamese fighting fish will not fight when paired with another male after a $48 \mathrm{~h}$ exposure to a $1 \mathrm{mg} / \mathrm{cc}$ solution of diethylamine HC1. Suppression of fighting is reversible with duration of suppression related to concentration of diethylamine $\mathrm{HCl}$ in the exposure solution. Loss of aggression is accompanied by vigorous retreat or escape behavior when confronted by an opponent.

Fighting behavior of Betta splendens can be experimentally manipulated by forebrain lesions (Noble \& Borne, 1941), avoidance conditioning (Phillips \& Stepter, 1966), food deprivation (Marrone, 1965), LSD-25 (Abramson \& Evans, 1954), toxic agents (Abramson, Weiss, \& Baron, 1958), classical conditioning (Thompson \& Sturn, 1965), tranquilizers (Walaszek \& Abood, 1956), and previous fighting experience (one fish successively paired with a number of opponents will consequently exhibit reduced fighting behavior).

A chemical synthesis to prepare dimethylacetamide (Weiss, Mancall, Knoltes, White, \& Jackson, 1962) for testing with Siamese fighting fish accidentally yielded a compound with some interesting behavioral effects. Infrared spectral analysis and melting point (224-227 ${ }^{\circ}$ identified the substance as diethylamine $\mathrm{HCl}$.

Preliminary test with an adult male fish of $7 \mathrm{~cm}$ length exposed in $250 \mathrm{cc}$ of $2 \mathrm{mg} / \mathrm{cc}$ tap water solution of diethylamine $\mathrm{HCl}$ for $48 \mathrm{~h}$ clearly suppressed fighting behavior (biting, chasing, tail whipping, fanning) when paired with an untreated male of the same length. The treated male was dominant prior to exposure; after exposure the treated male did not fight at all and retreated vigorously when approached by the untreated fish. The same flsh were paired on several occasions during several days following exposure and the same behavior was observed on each occasion. Two additional adult male fish were treated in the same manner, with the same suppression of fighting being observed in the treated fish.

Method

Forty furenile male fish (3-5 cm in length) were used in a more extensive test of the original observations. Juvenile males appear to be as aggressive in fighting as the actult males, but they are less effective in seriously damaging their opponent. All fish were obtained from a local wholesale dealer, and were in apparently good health at the beginning of the experiment. Each fish was individually maintained in a separate tank at all times except during observation periods of $10 \mathrm{~min}$ duration. Tap water was used in all tanks, and all fish were fed twice daily on recommended fish food (TetraMin).
Ten pairs of fish were observed for fighting behavlor and all pairs exhibited the typical fighting responses. One fish was randomly selected from each pair and exposed $48 \mathrm{~h}$ in $60 \mathrm{cc}$ of a $1 \mathrm{mg} / \mathrm{cc}$ concentration of diethylamine $\mathrm{HCl}$ solution. Ten min observations were then made $0,24,28,32,36,40,44$, and $48 \mathrm{~h}$ postexposure after reuniting each pair in a 500 cc observation bowl.

The unexposed fish in the first pairing were then paired with 10 additional fish (unexposed), and all pairs were observed to exhibit fighting. From each pair, one fish was randomly selected and exposed to a $2 \mathrm{mg} / \mathrm{cc}$ concentration of diethylamine $\mathrm{HCl}$ solution. Postexposure testing followed the same procedure as with the first group.

The unexposed fish in the second group were then paired with the 10 remaining unexposed flsh and again observed for fighting behavior. All pairs fought. Ten randomly selected fish from this group were then kept in $60 \mathrm{cc}$ of tap water for $48 \mathrm{~h}$ in the same containers as the preceding experimental groups, and subsequently tested for fighting in the same manner as were Groups 1 and 2.

\section{Resulfs and Discussion}

No treated fish fought immediately after exposure and no control pair failed to flght after sham exposure. Duration of fighting suppression was related to exposure concentration of diethylamine $\mathrm{HCl}$; fish in a $2 \mathrm{mg} / \mathrm{cc}$ concentration began flghting $32 \mathrm{~h}$ following exposure, whereas fish in a $1 \mathrm{mg} / \mathrm{cc}$ concentration began fighting 24 h following exposure.

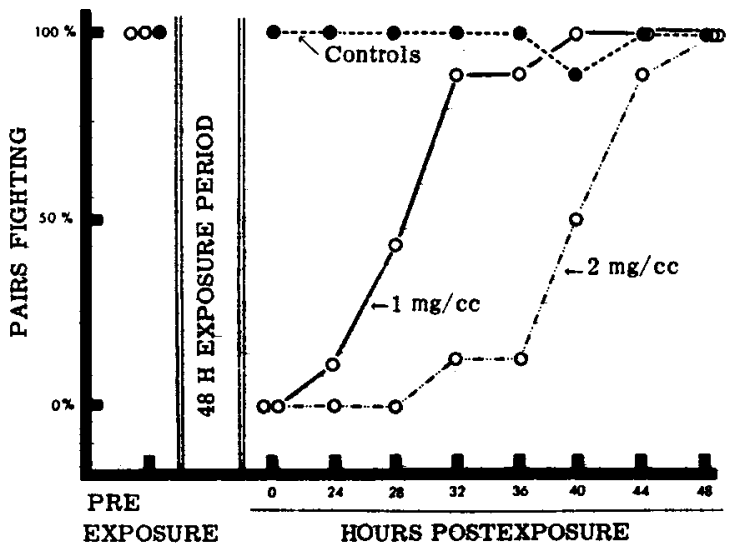

Fig. 1. Suppression of fighting behavior in paired male jurenile Simese fighting fish exposed to two concentrations of diethylamine $\mathrm{HCl}$ solutions. Control animals were exposed to tap water in the same containers. 
One treated fish died in the first exposure group (1 $\mathrm{mg} / \mathrm{cc}$ ) and two fish died in the second exposure group (all deaths occurring during exposure). One fish in the control group died due to jumping out of the $60 \mathrm{cc}$ sham exposure bowl. No detrimental effects were noted in any fish after the recovery period. Concentration of diethylamine $\mathrm{HCl}$ as high as $20 \mathrm{mg} / \mathrm{cc}$ of water does not appreciably alter the $\mathrm{pH}$ of the solution.

The behavior of treated fish following exposure appears normal except for changes in pigmentation, fin display, and aggressive behavior towards another male. Avoidance of other fish is particularly prominent in treated fish, and can be noted by vigorous and erratic escape behavior when approached by another male. The peculiar escape behavior may be similar to that reported by Walaszyek \& Abood (1956) following exposure to Phenergan, Pyribenzamine, Benadryl, and Atarax, all well known psychoactive compounds.

References

ABRAMSON, H. A., \& EVANS, L. T. Lysergic acid diethylamide (LSD
25): II. Psychological effects on the Siamese fighting fish. Science, 1954, 120, 990-991.

ABRAMSON, H. A., WEISS, B., \& BARON, M. O. Comparison of effect of LSD, potassium cyanide, and other respiratory inhibitors on Betta splendens Nature, 1958, 181, 1136.

MARRONE, R. L. Effects of food deprivation on the fighting response of Betta splendens. Psychol Rep., 1965, 17, 632.

NOBLE, G. K., \& BORNE, R. The effect of forebrain lesions on the sexual and fighting behavior of Betta splendens and other fishes. Anat. Rec., 1941, 79 (3), suppl. 2, 49. (Abstract)

PHILLIPS, J. D., \& STEPTER, G. D. Elimination of fighting response in Siamese fighting fish with avoidance conditioning. Paper read at Midwest. Psychol. meeting in Chicago, 1966.

THOMPSON, T., \& STURM, T. Classical conditioning of aggressive display in Siamese fighting fish. J. exp. Anal. Behav., 1965, 8, 397-404.

WALASZEK, E. J., \& ABOOD, L. G. Effect of tranquilizing drugs on fighting response of Siamese fighting fish. Science, 1956, 124, 440-441.

WEISS, A. J., MANCALL, E. L., KNOLTES, J. A., WHITE, J. C., \& JACKSON, L. G. Dimethylacetamide: A hitherto unrecognized hallucinogenic agent. Science, 1962, 136, 151-152.

Note

1. Now at Edward R. Johnstone Training and Research Center, Bordentown, N. J. 08505. 